\title{
INDUKSI TUNAS DARI NODUL KRISAN KULO DALAM MEDIA MURASHIGE DAN SKOOG YANG DIBERI SITOKININ
}

\author{
SHOOT INDUCTION FROM NODAL SEGMENTS OF THE KULO CHRYSANTHEMUM \\ VARIETY IN CYTOKININ-ENHANCED MURASHIGE AND SKOOG GROWTH MEDIA
}

\author{
W. Tilaar, J. Rantung dan S. Tulung*) \\ *)Fakultas Pertanian Universitas Sam Ratulangi Manado
}

\begin{abstract}
The kulo chrysanthemum variety is a North Sulawesi local variety characterized by large white flowers. The new variety was introduced barely two years ago, yet it has gained considerable popularity among flower farmers in Tomohon City as well as in Manado, Tondano, and around the Minahasa and North Minahasa regencies. The growing interest in this particular variety has increased the demand for nursery stock resulting in a shortage of supply. The conventional plantlet propagation method i.e. one seed to grow one plant, is deemed very time consuming and has poor plantlet yield. It is therefore necessary to explore other plantlet propagation methods that can produce high yield in a relatively short period of time. One of the best techniques for plantlet propagation is tissue culture. The success of tissue culture in producing high plantlet yield is determined by the use of appropriate plant growth regulators. Accurate concentrations of growth regulators are vital in achieving an optimum yield. Consequently, determining the exact concentrations is a major issue in the tissue culture method. Cytokinins are commonly used as growth regulators in shoot and plantlet propagations. However, different types of cytokinins may have different effects on shoot generation from the nodal explants used in particular in vitro propagations. The kulo chrysanthemum variety has never been propagated using the nodal explant tissue culture technique and may respond differently than other varieties. Therefore, it is essential to determine which types of cytokinins are most suited to stimulate its shoot and plantlet propagations.
\end{abstract}

Keywords: propagation, chrysanthemum nodes, murashige, skoog, BAP, kinetin, and NAA

\section{ABSTRAK}

Tanaman krisan varietas kulo merupakan varietas lokal di Sulawesi Utara dengan bunga besar dan berwarna puth. Tanaman tersebut baru dua tahun dilepas sebagai varietas baru dan sangat disukai oleh petani bunga di kota Tomohon bahkan secara luas di Manado dan Tondano serta daerah Minahasa dan Minahasa Utara. Banyaknya peminat terhadap jenis bunga ini menyebabkan kebutuhan bibitnya bertambah pula sehingga terjadi kekurangan bibit. Jika menggunakan teknik perbanyakan bibit secara konvensional yaitu tanam satu benih maka akan menghasilkan satu tanaman saja sehingga sangat lambat dan sedikit sekali untuk ketersediaan bibitnya dan berarti produksi tanaman sangat rendah. Sebab itu dicari teknik perbanyakan bibit yang cepat dan menghasilkan bibit yang banyak dengan waktu relatif singkat. Salah satu teknik yang sangat tepat untuk mendapatkan bibit yang banyak adalah teknik perbanyakan melalui kultur jaringan. Kesuksesan kultur jaringan ditentukan oleh zat pengatur tumbuh yang tepat sehingga diperoleh bibit yang banyak. Zat pengatur tumbuh harus tepat konsentrasinya sehingga dapat merangsang perbanyakan bibit yang optimal. Hal tersebut meruapakan permasalahan dalam teknik kultur jaringan untuk perbanyakan bibit. Sitokinin adalah zat pengatur tumbuh yang sering digunakan untuk perbanyakan tunas dan bibit. Namun Jenis sitokinin yang berbeda ini menentukan terjadinya tunas dari eksplan nodul yang akan digunakan dalam perbanyakan in vitro tersebut. Tanaman varietas kulo belum pernah dilakukan perbanyakan bibit melalui kultur jaringan menggunakan eksplan nodul atau buku batang dan berbeda responsnya dengan varietas lainnya. Sebab itu perlu untuk dicarikan Jenis sitokini dalam mendukung perangsangan pembentukan tunas dan bibit baru.

Kata kunci : propagasi, nodul krisan, murashige, skoog , BAP, kinetin dan NAA 


\section{PENDAHULUAN}

Tanaman krisan termasuk tanaman hias yang mempunyai nilai keindahan pada bunganya. Selain sebagai tanaman penghias taman atau sebagai tanaman pot yang menarik, tanaman krisan juga dapat digunakan sebagai obat tradisional, obat penghasil racun serangga dan dapat digunakan sebagai bunga potong yang dapat bersaing dengan bunga-bunga potong lainnya. Di Indonesia bunga krisan merupakan bunga potong yang cukup populer dan menduduki urutan tertinggi di antara bunga potong non anggrek. Hal ini disebabkan karena krisan mempunyai bau yang harum, bentuk dan ukuran bunga yang bervariasi serta warna yang beraneka ragam sehingga memberikan daya tarik tersendiri (Ashari, 1995). Secara etimologi, krisan berasal dari Bahasa Yunani yang terdiri dari dua kata, Chrys yang berarti emas, dan anthemion yang berarti bunga. Karena itu, krisan sering diartikan sebagai bunga emas.

Permintaan akan bunga potong khususnya krisan di kota-kota besar seperti: Jakarta, Bandung, Malang, Manado, dan Denpasar meningkat ratarata 10\% per tahun (Sarwono, 1992). Pada tahun 1993 eksport krisan sebanyak 198,3 ton senilai US \$243,7 ribu ke Jepang, Hongkong, Malaysia, dan Singapura, sedangkan pada tahun yang sama import krisan sebanyak 3,8 ton, senilai US \$22,1 ribu dari Belanda dan Malaysia, dengan demikian surplus sebesar U\$ 221,6 ribu. Tahun 1999 kebutuhan krisan di DKI sebanyak 12.220.800 tangkai. Menurut Direktorat Jenderal Hortikultura, produksi krisan meningkat sejak 2005 sampai 2010 yaitu tahun 2005 ada 47.465 .794 batang dan pada tahun 2010 ada 120.485 .701 batang. Ini dapat dilihat pada Tabel 1. Kemudian target dari Direktorat Jenderal Hortikultura pada tahun 2014 untuk produksinya mencapai 352.956 .738 tangkai bunga (Tabel 2).

Khususnya dalam pengembangan di Tomohon bahwa potensi bisnis krisan memang sangat besar. Dari kebun seluas $1 \mathrm{~m}^{2}$ saja dapat diproduksi sekitar 100 tangkai krisan dengan harga Rp1.000/tangkai, bahkan Rp. 2.000/tangkai untuk bunga berukuran besar. Sementara biaya produksi hanya sekitar Rp. 250 - Rp. 650 per tangkai.
Direktorat Budidaya dan Pascapanen Florikultura mempunyai misi kemandirian industri krisan dalam negeri untuk membantu peningkatan pendapatan petani. Tomohon memiliki potensi pengembangan lahan krisan sekitar 50 ha. Potensi inilah yang membuat kabupaten ini dijadikan pusat pengembangan krisan untuk wilayah Indonesia Timur. Varietas Krisan Kulo (putih) dan Ririh (kuning) menjadi andalan Kota Tomohon yang diluncurkan pada rangkaian Tomohon International Flower Festival (TIFF) 2012 yang diselenggarakan pada 8-12 Agustus 2012 lalu. Ajang dua tahunan ini diikuti oleh enam negara, yaitu Belanda, Prancis, Amerika Serikat, Korea Utara, Filipina, dan Indonesia (Diennazola, 2012).

Dengan semakin meningkatnya permintaan akan krisan maka perlu diupayakan sistem budidaya tanama krisan yang lebih baik, terutama dalam hal perbanyakan dan kualitas bibit karena dengan perbanyakan secara konvensional membutuhkan waktu yang lebih lama dan kualitas tanaman yang dihasilkan kurang baik misalnya bibit sering terserang hama dan penyakit. Salah satu alternatif untuk mendapatkan tanaman dalam jumlah banyak dan dalam waktu singkat adalah dengan dilakukan perbanyakan secara in-vitro melalui teknik kultur jaringan.

Tehnik kultur jaringan adalah salah satu teknik dimana bagian tanaman yang telah diisolasi misalnya sel, protoplasma, jaringan, atau organ tanaman dikulturkan pada lingkungan yang sesuai dalam kondisi aseptic sehingga dapat tumbuh dan berkembang menjadi tanaman baru. Keberhasilan teknik kultur ini ditentukan oleh beberapa faktor seperti genotipa tanaman, media tumbuh, zat pengatur tumbuh dan lingkungan lainnya.

Zat pengatur tumbuh adalah senyawa organik yang dalam jumlah yang sedikit dapat mengendalikan pertumbuhan dan perkembangan tanaman seperti jaringan kalus atau potongan organ tanaman yang ditumbuhkan dalam media dengan diberi sitokinin akan merangsang pembentukan organ tunas baru. Zat pengatur tumbuh ini dapat berupa sintetik dan fitohormon. Salah satu zat pengatur tumbuh yang digunakan untuk pembentukan tunas yang berasal dari pucuk krisan adalah Benzilaminopurin (BAP). Zat pengatur tumbuh ini 
lebih efektif dari zat pengatur tumbuh golongan sitokinin. Dari beberapa penelitian menunjukkan lebih berhasil dalam merangsang pembentukan tunas. Hasil penelitian Sompotan dan Tilaar ( 2008) menunjukan dengan pemberian BAP pada media MS dengan konsentrasi 1 - 5 ppm menghasilkan tunas-tunas baru. Selain itu pula Tilaar dan Rantung (2013) telah meneliti tentang propagasi in vitro eksplan pucuk krisan kulo dengan menggunakan NAA dan BAP dengan hasil perbanyakan tunas yang terbanyak adalah pada $1 \mathrm{ppm}$ BAP yaitu 8,2 tunas. Untuk hasil tunas pada perlakuan kombinasi 0,5 ppm: 1 ppm NAA dan 1 ppm BAP sangat kurang yaitu hanya 2,4 dan 1,8 tunas. Jadi NAA jika dikombinasikan dengan BAP bersifat menghambat perbanyakan tunas krisan kulo Sebab itu perlu diteliti lebih lanjut tentang pengaruh beberapa jenis sitokinin dalam perbanyakan tunas krisan kulo ini. Adapun jenis atau varietas yang digunakan adalah varietas lokal berasal dari Kota Tomohon yaitu Varietas Kulo. Varietas ini diunggulkan di Tomohon sebab memiliki ukuran bunga yang besar dan berwarna putih dengan bentuk bunga yang unik. Sebab itu dinamakan Varietas Kulo yang artinya berwarna putih. Pemerintah Kota Tomohon ber- usaha untuk mengembangkannya sebagai ikon bagi daerah ini sekaligus dinilai dapat memberikan keuntungan dengan menanam bunga krisan tersebut. Namun permasalahan adalah kekurangan bibit krisan sebagai awal proses produksi tanaman tersebut. Sebab itu untuk mempercepat pengadaan bibit dapat menggunakan teknik kultur jaringan. Beberapa penelitian sudah dilakukan tentang perbanyakan in vitro pada krisan, namun jenisnya berbeda dengan Varietas Kulo, sehingga kemungkinan responnya berbeda terhadap beberapa jenis zat pengatur tumbuh sitokinin. Sebab itu perlu diteliti terhadap eksplan nodul Varietas Kulo ini untuk ditumbuhkan pada media yang diberi beberapa jenis sitokinin sehingga diperoleh hasil jenis sitokinin mana yang terbaik untuk perbanyakan tunas secara in vitro.

Penelitian ini bertujuan untuk: 1) mengetahui pengaruh beberapa jenis sitokinin terhadap perbanyakan bibit dari eksplan nodul Krisan Varietas Kulo; 2) mendapatkan bibit Krisan Kulo yang lebih banyak dalam waktu yang relatif singkat untuk disiapkan pada petani bunga krisan sekaligus dapat meningkatkan produksi dan pendapatan petani tersebut.

Tabel 1. Produksi Krisan Di Indonesia Tahun 2005-2010

(Table 1. Chrysanthemum Production of Indonesia in 2005-2010)

\begin{tabular}{lcccccc}
\hline \multirow{2}{*}{$\begin{array}{c}\text { Produksi } \\
\text { Krisan }\end{array}$} & 2005 & 2006 & 2007 & 2008 & 2009 & 2010 \\
& tangkai & tangkai & tangkai & tangkai & tangkai & tangkai \\
\hline Krisan secara & 47.465 .794 & 63.716 .256 & 66.979 .260 & 101.777 .126 & 107.847 .072 & 120.485 .701 \\
nasional & & & & & & \\
$\begin{array}{l}\text { Peningkatan } \\
\begin{array}{l}\text { Persentasi } \\
\text { peningkatan }\end{array}\end{array}$ & & 16.250 .462 & 3.263 .004 & 34.797 .866 & 6.069 .946 & 12.638 .629 \\
& & $34,2 \%$ & $5,1 \%$ & $52 \%$ & $6 \%$ & $11,7 \%$ \\
\hline
\end{tabular}

Sumber : Strategis Perencanaan dari Direktorat Jenderal Hortikultura 2010

Tabel 2. Target Produksi Krisan tahun 2010- 2014 oleh Direktorat Jenderal Hortikultura

(Table 2. The Chrysanthemum Production Target for 2010-2014 of the Directorate-General of Horticulture)

\begin{tabular}{cccccc}
\hline \multirow{2}{*}{ Produksi Krisan } & \multicolumn{5}{c}{ Tahun } \\
\cline { 2 - 6 } & 2010 & 2011 & 2012 & 2013 & 2014 \\
& tangkai & tangkai & tangkai & tangkai & tangkai \\
\hline Produksi nasional & 248.080 .490 & 270.770 .892 & 295.661 .436 & 322.888 .796 & 352.956 .738 \\
Target Peningkatan (\%) & & $22,690.402$ & 24.890 .544 & 27.227 .360 & 30.670 .942 \\
& & $9,1 \%$ & $9,2 \%$ & $9,2 \%$ & $9,3 \%$ \\
\hline
\end{tabular}

Sumber :Strategi Perencanaan Direktorat Jenderal Hortikultura 2010- 2014. 


\section{METODE PENELITIAN}

Penelitian ini dilaksanakan di Laboratorium Bioteknologi Pertanian Fakultas Pertanian Unsrat selama 8 bulan dengan dua tahap. Tahap I adalah tahap perbanyakan tunas dan tahap II pembentukan plantlet dari tunas sebagai lanjutan dari tahap I.

Penelitian ini menggunakan Rancangan Acak Lengkap (RAL), dengan 5 ulangan. Untuk tahap I perbanyakan tunas yaitu jenis sitokinin
(Benzilaminopurin; Kinetin ) dengan konsenterasi yang digunakan $0 ; 1 ; 2 ; 3$ ppm. Kemudian tahap II pembentukan plantlet menggunakan rancangan acak lengkap dengan perlakuan $0 ; 0,5 ; 1 \mathrm{ppm}$ NAA. Sedangkan untuk tahap aklimatisasi dilakukan dengan menanam plantlet ke polibag dengan menggunakan pupuk kandang dan tanah $1: 3$.

Untuk road map penelitian dapat dilihat pada bagan di bawah ini.

\section{Road Map penelitian Krisan varietas kulo}

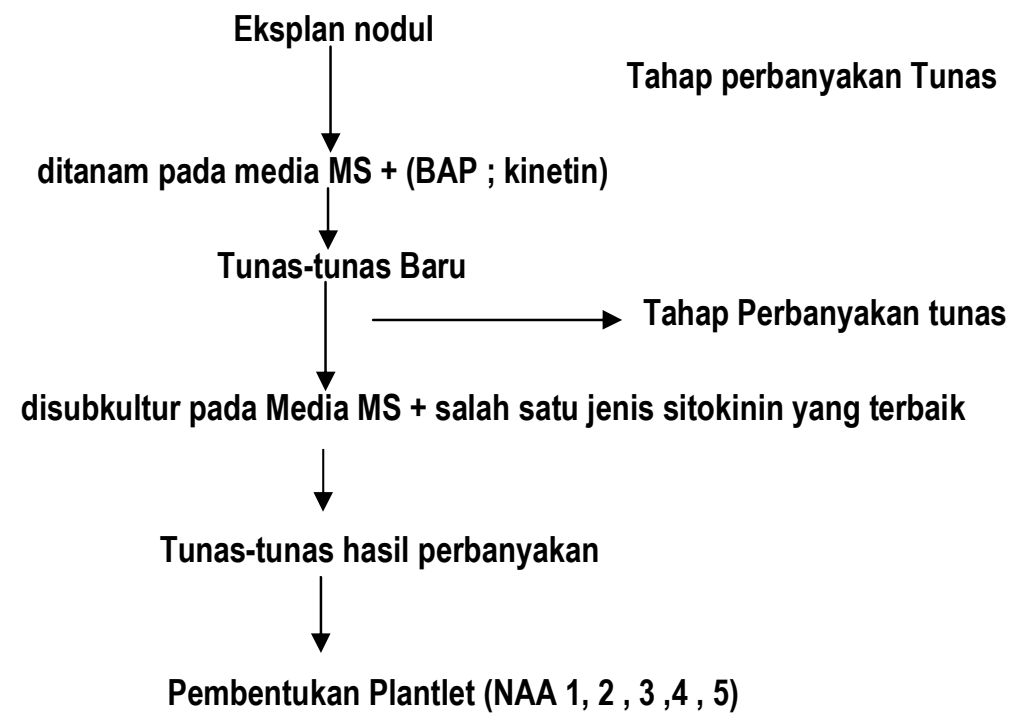

Variabel yang diamati :

- tinggi tunas (pengamatan minggu ke 8)

- Jumlah tunas (pengamatan dilakukan minggu ke-8 sesudah tanam)

- Berat basah tunas (pengamatan dilakukan minggu ke-8 sesudah tanam)

- Jumlah akar

- panjang akar

Analisis statistik yang digunakan adalah analisis varians yang dilanjutkan dengan Uji BNT.

\section{HASIL DAN PEMBAHASAN}

\section{Perbanyakan Tunas BENZILAMINOPURIN Tinggi Tunas}

Berdasarkan hasil analisis ragam menunjukkan bahwa BAP berpengaruh nyata terhadap tinggi tunas. Rataan tunas tertinggi adalah pada perlakuan 1 ppm BAP. Tinggi tunas semakin menurun bilamana konsentrasi BAP semakin tinggi. Selanjutnya dilakukan uji BNT yang dapat dilihat pada Tabel 3.

Hasil uji BNT menunjukan bahwa tinggi tunas pada perlakuan BAP $1 \mathrm{ppm}$ tidak berbeda nyata dengan perlakuan 0 ppm BAP tetapi berbeda nyata dengan tinggi tunas pada perlakuan 2 dan 3 ppm BAP. Semakin tinggi konsentrasi BAP menghambat pertambahan tinggi tunas.

\section{Jumlah Tunas}

Hasil analisis ragam menunjukkan bahwa pengaruh BAP terhadap jumlah tunas tidak berbeda nyata. Jadi semua perlakuan sama pengaruhnya terhadap jumlah tunas. Ini mungkin disebabkan karena jenis Krisan Kulo adalah jenis lokal 
sehingga kurang responnya terhadap pembentukan tunas-tunas baru dan ini mengakibatkan jumlah tunas tidak lagi dipengaruhi oleh BAP, atau juga sebaliknya bahwa BAP tidak sesuai dengan genetik tanaman tersebut sehingga pembentukan tunas hampir sama antara perlakuan. Sebab jenis zat pengatur tumbuh mempunyai karakter yang berbeda sehingga genetik maupun fisiologis dari tanaman tersebut tidak merespons dengan baik.

\section{Jumlah Daun}

Berdasarkan hasil analisis ragam menunjukkan bahwa BAP mempengaruhi terhadap jumlah daun. Terdapat perbedaan pengaruh antara perlakuan dengan perlakuan lainnya. Sebab itu dilanjutkan dengan Uji BNT $5 \%$ sebagaimana pada Tabel 5.

Tabel 3. Pengaruh BAP Terhadap Tinggi Tunas

(Table 3. Effect of BAP on Shoot Height)

\begin{tabular}{cc}
\hline Perlakuan & Rata-rata Tinggi Tunas \\
\hline 0 & $8,50 \mathrm{bc}$ \\
1 & $9,58 \mathrm{c}$ \\
2 & $5,82 \mathrm{ab}$ \\
3 & $4,54 \mathrm{a}$ \\
\hline BNT 5\% & $3,0,3$ \\
\hline
\end{tabular}

Keterangan: Angka yang diikuti dengan huruf yang sama, tidak berbeda nyata berdasarkan uji BNT 5\%

Tabel 4. Analisis Ragam dari Pengaruh BAP terhadap Jumlah Tunas

(Table 4. Analysis of Variance on the Effect of BAP on Shoot Quantity)

\begin{tabular}{lrcccc}
\hline $\begin{array}{c}\text { Sumber } \\
\text { keragaman }\end{array}$ & $\mathrm{db}$ & Jumlah Kuadrat & Kuadrat Tengah & F Hitung & F Tabel 5\% \\
\hline Perlakuan & 3 & 1,349999 & 0,450000 & 2,250 ns & 3,24 \\
Galat & 16 & 4,200000 & 0,200000 & & \\
\hline Total & 19 & 4,549999 & & & \\
\hline
\end{tabular}

$\mathrm{KK}=38,89 \%$

Keterangan $: \mathrm{ns}=$ non signifikan

Tabel 5. Pengaruh BAP Terhadap Jumlah Daun

(Table 5. Effect of BAP on Leaf Quantity)

\begin{tabular}{cc} 
Perlakuan & Rata-rata Jumlah Daun \\
\hline 0 & $21,60 \mathrm{~b}$ \\
1 & $14,20 \mathrm{ab}$ \\
2 & $10,60 \mathrm{a}$ \\
3 & $11,80 \mathrm{a}$ \\
\hline BNT 5\% & 7,48
\end{tabular}

Keterangan: Angka yang diikuti dengan huruf yang sama, tidak berbeda nyata berdasarkan uji BNT 5\% 
Tabel 6. Pengaruh BAP Terhadap Jumlah Akar

(Table 6. Effect of BAP on Root Quantity)

\begin{tabular}{cc}
\hline Perlakuan & Rata-rata Jumlah Akar \\
\hline 0 & $11,80 \mathrm{abc}$ \\
1 & $9,20 \mathrm{ab}$ \\
2 & $8,40 \mathrm{a}$ \\
3 & $17,40 \mathrm{c}$ \\
\hline BNT 5\% & 5,90
\end{tabular}

Keterangan: Angka yang diikuti dengan huruf yang sama, tidak berbeda nyata berdasarkan uji BNT 5\%

Hasil analisis statistik menunjukkan bahwa BAP 3 ppm tertinggi jumlah akarnya dan tidak berbeda nyata dengan 0 ppm BAP.tetapi berbeda nyata dengan perlakuan 1 dan 2 ppm BAP. Jumlah akar yang tidak berbeda antara perlakuan $0 \mathrm{ppm}$ dan 3 ppm BAP, mungkin pada perlakuan 3 ppm BAP belum atau sangat lambat tersedia sehingga auksin endogen lebih cepat tersedia sehingga terbentuk akar yang lebih banyak dan sama dengan perlakuan 0 ppm BAP. Selanjutnya perlakuan tanpa BAP, perakarannya banyak disebabkan auksin endogen dari tunas langsung tersedia dan merangsang pembentukan akar.

\section{Panjang Akar}

Hasil analisis ragam menunjukan bahwa BAP dalam pengaruhnya terhadap panjang akar tidak berbeda nyata antar perlakuan. Artinya bahwa perlakuan BAP yang diberikan dalam media tidak memberikan peran yang berbeda. Jadi semuanya sama perannya dalam merangsang pertambahan panjang akar. Hal tersebut dapat dilihat pada tabel 7.

Dalam kaitan dengan rangsangan zat pengatur tumbuh BAP terhadap panjang akar, bahwa secara fisiologis BAP tidak merangsang pertambahan panjang akar. Sebab itu perannya terhadap panjang akar tidak ada.

\section{Berat Tunas}

Hasil analisis ragam menunjukkan bahwa berat tunas dipengaruhi oleh perlakuan-perlakuan BAP. Pengaruh ini adalah sebagai pengaruh tidak langsung. Contoh dengan adanya jumlah tunas yang banyak maka terjadi pertambahan berat yang signifikan. Adanya perbedaan pengaruh maka dilakukan Uji statistik untuk mengetahui perlakuan mana saja yang berbeda. Hal tersebut dapat dilihat pada Tabel 8.
Dari data pada tabel 8 menunjukan bahwa berat tunas tertinggi adalah pada perlakuan $1 \mathrm{ppm}$ BAP dimana tidak berbeda nyata dengan perlakuan 0 ppm BAP tetapi berbeda nyata dengan perlakuan 2 ppm BAP dan 3 ppm BAP. Mungkin disebabkan karena batangnya dan tinggi tunasnya yang lebih tinggi dari perlakuan lainnya. Hal ini dapat dilihat pada data Tabel 9.

\section{KINETIN}

\section{Tinggi Tunas}

Hasil analisis ragam menunjukan bahwa Kinetin tidak berbeda pengaruhnya terhadap tinggi tunas, disini peran dari zat pengatur tumbuh kinetin sangat rendah.

\section{Jumlah Tunas}

Berdasarkan analisis ragam menunjukkan bahwa kinetin berpengaruh nyata terhadap jumlah tunas Krisan Kulo. Pengaruh dari kinetin terhadap jumlah tunas adalah berbeda nyata antara perlakuan, oleh sebab itu dilakukan uji BNT sebagaimana pada Tabel 10

Dari Tabel 10 menunjukan bahwa perlakuan 3 ppm kinetin berbeda nyata dengan $0 ; 1$; dan 2 ppm kinetin. Dari hasil analisis statistik memperlihatkan bahwa semakin tinggi konsenterasi kinetin semakin merangsang pembentukan tunas.

\section{Jumlah Daun}

Hasil analisis ragam menunjukan bahwa kinetin tidak berpengaruh nyata terhadap jumlah daun. Jadi pengaruhnya sama terhadap jumlah daun. Kinetin adalah zat pengatur tumbuh gologan sitokinin berfungsi dalam pertumbuhan tetapi juga berperan dalam morfogenesis tunas. Jadi perannya bukan untuk merangsang pembentukan daun. 
Tabel 7. Analisis Ragam dari Pengaruh BAP terhadap Panjang Akar

(Table 7. Analysis of Variance on the Effect of BAP on Root Length)

\begin{tabular}{lccccc}
\hline \multicolumn{1}{c}{ Sumber keragaman } & $\mathrm{db}$ & Jumlah kuadrat & Kuadrat tengah & F Hitung & F Tabel 5\% \\
\hline Perlakuan & 3 & 15,797473 & 5,265824 & $1,160 \mathrm{~ns}$ & 3,24 \\
Galat & 16 & 72,652054 & 4,540753 & & \\
\hline Total & 19 & 88,449524 & & & \\
\hline
\end{tabular}

KK $=38,02 \%$

Keterangan : ns= non significant

Tabel 8. Pengaruh BAP Terhadap Berat tunas Krisan

(Table 8. Effect of BAP on Shoot Weight)

\begin{tabular}{cc}
\hline Perlakuan & Rata-rata Berat Krisan/g \\
\hline 0 & $0,55 \mathrm{bc}$ \\
1 & $0,71 \mathrm{c}$ \\
2 & $0,21 \mathrm{a}$ \\
3 & $0,27 \mathrm{ab}$ \\
\hline BNT 5\% & 0,33
\end{tabular}

Keterangan: Angka yang diikuti dengan huruf yang sama, tidak berbeda nyata berdasarkan uji BNT 5\%

Tabel 9. Analisis Ragam Pengaruh Kinetin Terhadap Tinggi Tunas.

(Table 9. Analysis of Variance on the Effect of Kinetin on Shoot Height)

\begin{tabular}{lccccc}
\hline Sumber keragaman & $\mathrm{db}$ & Jumlah kuadrat & Kuadrat tengah & F Hitung & F Tabel 5\% \\
\hline Perlakuan & 3 & 26,173412 & 8,724471 & $1,509 \mathrm{~ns}$ & 3,24 \\
Galat & 16 & 92,516037 & 5,782252 & & \\
\hline Total & 19 & 118,689453 & & & \\
\hline KK $=32,08 \%$ & & & &
\end{tabular}

$\mathrm{KK}=32,08 \%$

Keterangan : ns= non significant

Kinetin ini secara fisiologis kurang merangsang dalam tinggi tunas.

Tabel 10. Pengaruh Kinetin Terhadap Jumlah Tunas

(Table 10. Effect of Kinetin on Shoot Quantity)

\begin{tabular}{cc}
\hline Perlakuan & Rata-rata Jumlah Tunas \\
\hline 0 & $2,20 \mathrm{a}$ \\
1 & $2,20 \mathrm{a}$ \\
2 & $3,00 \mathrm{a}$ \\
3 & $6,20 \mathrm{~b}$ \\
\hline BNT 5\% & 2,28
\end{tabular}

Keterangan: Angka yang diikuti dengan huruf yang sama, tidak berbeda nyata berdasarkan uji BNT 5\%.

\section{Jumlah Akar}

Hasil analisis ragam menunjukan bahwa kinetin tidak berpengaruh nyata terhadap jumlah akar. Jadi pengaruhnya sama terhadap jumlah akar. Kinetin adalah zat pengatur tumbuh gologan sitokinin berfungsi dalam pertumbuhan tetapi juga berperan dalam morfogenesis tunas. Jadi perannya bukan untuk merangsang pembentukan akar.

\section{Panjang Akar}

Hasil analisis ragam menunjukan bahwa kinetin tidak berpengaruh nyata terhadap panjang akar. Jadi pengaruhnya antar perlakuan sama ter- 
hadap panjang akar. Kinetin adalah zat pengatur tumbuh gologan sitokinin berfungsi dalam pertumbuhan tetapi juga berperan dalam morfogenesis tunas. Jadi perannya bukan untuk merangsang pertambahan panjang akar.. beda nyata terhadap berat basah tunas krisan. Jadi semua perlakuan sama pengaruhnya terhadap berat basah krisan kulo. Ini mungkin disebabkan karena jenis tanaman yang kurang respons terhadap pemberian zat pengatur tumbuh kinetin.

\section{Berat Tunas}

Berdasarkan hasil analisis ragam menunjukkan bahwa kinetin pengaruhnya tidan ber-

Tabel 11. Analisis Ragam dari Pengaruh Kinetin terhadap Jumlah Daun

(Table 11. Analysis of Variance on the Effect of Kinetin on Leaf Quantity)

\begin{tabular}{lccccc}
\hline Sumber keragaman & $\mathrm{db}$ & Jumlah kuadrat & Kuadrat tengah & F Hitung & F Tabel 5\% \\
\hline Perlakuan & 3 & 670,150757 & 223,383591 & $1,406 \mathrm{~ns}$ & 3,24 \\
Galat & 16 & 2542,399902 & 158,899994 & & \\
\hline Total & 19 & 3212,550781 & & & \\
\hline KK $=$ & & & & \\
\hline
\end{tabular}

KK $=42,51 \%$

Keterangan : ns= non significant

Tabel 12. Analisis Ragam Pengaruh Kinetin terhadap Jumlah Akar

(Table 12. Analysis of Variance on the Effect of Kinetin on Root Quantity)

\begin{tabular}{lccccc}
\hline Sumber keragaman & $\mathrm{db}$ & Jumlah kuadrat & Kuadrat tengah & F Hitung & F Tabel 5\% \\
\hline Perlakuan & 3 & 212,550049 & 70,850014 & $2,751 \mathrm{~ns}$ & 3,24 \\
Galat & 16 & 412,000000 & 25,750000 & & \\
\hline Total & 19 & 624,550049 & & & \\
\hline KK & & & & & \\
\hline
\end{tabular}

KK $=47,65 \%$

Keterangan : ns= non significant

Tabel 13. Analisis Ragam dari Pengaruh Kinetin terhadap Panjang Akar

(Table 13. Analysis of Variance on the Effect of Kinetin on Root Length)

\begin{tabular}{lccccc}
\hline Sumber keragaman & $\mathrm{db}$ & Jumlah kuadrat & Kuadrat tengah & F Hitung & F Tabel 5\% \\
\hline Perlakuan & 3 & 16,785999 & 5,595333 & $1,543 \mathrm{~ns}$ & 3,24 \\
Galat & 16 & 58,023998 & 3,626500 & & \\
\hline Total & 19 & 74,809998 & & & \\
\hline KK $=45,89 \%$ & & & & &
\end{tabular}

KK $=45,89 \%$

Keterangan : ns= non significant

Tabel 14. Analisis Ragam dari Pengaruh Kinetin terhadap Berat Tunas.

(Table 14. Analysis of Variance on the Effect of Kinetin on Shoot Weight)

\begin{tabular}{lccccc}
\hline Sumber keragaman & $\mathrm{db}$ & Jumlah kuadrat & Kuadrat tengah & F Hitung & F Tabel $5 \%$ \\
\hline Perlakuan & 3 & 1,416900 & 0,472300 & $0,553 \mathrm{~ns}$ & 3,24 \\
Galat & 16 & 6,827326 & 0,853416 & & \\
\hline Total & 19 & 8,244226 & & & \\
\hline KK $=71,91 \%$ & & & & \\
\hline
\end{tabular}

$\mathrm{KK}=71,91 \%$

Keterangan : ns= non significant 


\section{Pembentukan Plantlet Tinggi Tunas}

Berdasarkan hasil analisis ragam menunjukkan bahwa NAA pengaruhnya tidak berbeda nyata terhadap tinggi tunas krisan. Jadi semua perlakuan sama pengaruhnya terhadap tinggi tunas krisan kulo. Ini mungkin disebabkan karena jenis tanaman yang kurang respons terhadap pemberian zat pengatur tumbuh NAA

\section{Jumlah Tunas}

Berdasarkan analisis ragam menunjukkan bahwa NAA berpengaruh nyata terhadap jumlah tunas krisan kulo. Pengaruh dari NAA terhadap jumlah tunas adalah berbeda nyata antara perlakuan. Sebab itu dilakukan uji BNT sebagaimana pada tabel 16

Jadi NAA $0 \mathrm{ppm}$ berbeda nyata dengan

NAA $1 ; 2 ; 3 ; 4$ dan 5 ppm dalam pengaruhnya terhadap jumlah tunas. Semakin tinggi NAA maka jumlah tunas semakin sedikit. Hasil tersebut menunjukkan adanya hambatan dari NAA terhadap jumlah tunas. Disebabkan fungsi dari NAA adalah merangsang perakaran dan ini menghambat pertunasan.

\section{Jumlah Akar}

Hasil analisis ragam menunjukkan bahwa NAA tidak berpengaruh nyata terhadap jumlah akar. Jadi pengaruhnya sama terhadap jumlah akar. NAA adalah zat pengatur tumbuh gologan auksin berfungsi dalam pertumbuhan akar tetapi juga berperan dalam perakaran. Jadi perannya seharusnya merangsang pembentukan akar. Hal ini mungkin NAA lama tersedia untuk merangsang perakaran.(Tabel 17).

Tabel 15. Pengaruh NAA terhadap Tinggi Tunas

(Table 15. Effect of NAA on Shoot Height)

\begin{tabular}{lccccc}
\hline Sumber keragaman & $\mathrm{db}$ & Jumlah kuadrat & Kuadrat tengah & F Hitung & F Tabel $5 \%$ \\
\hline Perlakuan & 5 & 58,245789 & 11,649158 & $1,4583 \mathrm{~ns}$ & 2,62 \\
Galat & 24 & 191,764038 & 7,990168 & & \\
\hline Total & 29 & 250,009827 & & &
\end{tabular}

KK $=50,45 \%$

Keterangan $: \mathrm{ns}=$ non significant

Tabel 16. Pengaruh NAA Terhadap Jumlah Tunas Krisan

(Table 16. Effect of NAA on Shoot Quantity)

\begin{tabular}{cc}
\hline Perlakuan & Rata-rata Jumlah Tunas \\
\hline $\mathrm{NAA}_{0}$ & $2,80 \mathrm{~b}$ \\
$\mathrm{NAA}_{1}$ & $1,60 \mathrm{a}$ \\
$\mathrm{NAA}_{2}$ & $1,20 \mathrm{a}$ \\
$\mathrm{NAA}_{3}$ & $1,00 \mathrm{a}$ \\
$\mathrm{NAA}_{4}$ & $1,00 \mathrm{a}$ \\
$\mathrm{NAA}$ & $1,00 \mathrm{a}$ \\
\hline BNT 5\% & 1,15 \\
\hline
\end{tabular}

Keterangan: Angka yang diikuti dengan huruf yang sama, tidak berbeda nyata berdasarkan uji BNT 5\%.

Tabel 17. Pengaruh NAA terhadap Jumlah Akar

(Table 17. Effect of NAA on Root Quantity)

\begin{tabular}{lccccc}
\hline Sumber keragaman & $\mathrm{db}$ & Jumlah kuadrat & Kuadrat tengah & F Hitung & F Tabel 5\% \\
\hline Perlakuan & 5 & 215,066559 & 43,013313 & $1,044 \mathrm{~ns}$ & 2,62 \\
Galat & 24 & 988,400024 & 41,183334 & & \\
\hline Total & 29 & 1203,466553 & & & \\
\hline KK $=60,92 \%$ & & & & \\
\hline
\end{tabular}

KK $=60,92 \%$

Keterangan : $\mathrm{ns}=$ non significant 


\section{Jumlah Daun}

Hasil analisis ragam menunjukkan bahwa NAA tidak berpengaruh nyata terhadap jumlah daun. Jadi pengaruhnya sama terhadap jumlah daun. NAA adalah zat pengatur tumbuh gologan auksin berfungsi dalam pertumbuhan tetapi juga berperan dalam morfogenesis tunas. Jadi perannya bukan untuk merangsang pembentukan daun (Tabel 18).

\section{Panjang Akar}

Hasil analisis ragam menunjukkan bahwa NAA tidak berpengaruh nyata terhadap panjang akar. Jadi pengaruhnya sama terhadap panjang akar. NAA adalah zat pengatur tumbuh gologan auksin berfungsi dalam pertumbuhan tetapi juga berperan dalam morfogenesis akar. Jadi perannya untuk merangsang pembentukan akar hanya mungkin karena belum tersedia maka belum berpengaruh terhadap panjang akar (Tabel 19).

\section{Berat Tunas}

Hasil analisis ragam menunjukkan bahwa NAA berpengaruh nyata terhadap berat tunas. Jadi pengaruhnya berbeda terhadap jumlah daun. NAA adalah zat pengatur tumbuh gologan auksin berfungsi dalam pertumbuhan tetapi juga berperan dalam morfogenesis akar. Jadi perannya bukan untuk merangsang pembentukan tunas.(Tabel 20).

Hasil tersebut bertolak belakang dengan fungsi dari auksin, tetapi dalam pengaruhnya bersifat negatif bahwa semakin tinggi konsenterasi NAA semakin sedikit berat tunas. Jadi menghambat dalam pertambahan berat.

Tabel 18. Analisisn Ragam dari Pengaruh NAA terhadap Jumlah Daun

(Table 18. Analysis of Variance on the Effect of NAA on Leaf Quantity)

\begin{tabular}{lccccc}
\hline Sumber Keragaman & $\mathrm{db}$ & Jumlah Kuadrat & Kuadrat tengah & F Hitung & F Tabel 5\% \\
\hline Perlakuan & 5 & 322,000183 & 64,400040 & $1,165 \mathrm{~ns}$ & 2,62 \\
Galat & 24 & 1327,199951 & 55,299999 & & \\
\hline Total & 29 & 1649,200195 & & & \\
\hline KK & & & & & \\
\hline
\end{tabular}

$\mathrm{KK}=51,64 \%$

Keterangan $: \mathrm{ns}=$ non significant

Tabel 19. Analisis Ragam dari Pengaruh NAA terhadap Panjang Akar

(Table 19. Analysis of Variance on the Effect of NAA on Root Length)

\begin{tabular}{lccccc}
\hline Sumber Keragaman & $\mathrm{db}$ & Jumlah Kuadrat & Kuadrat tengah & F Hitung & F Tabel 5\% \\
\hline Perlakuan & 5 & 26,374634 & 5,274927 & $0,604 \mathrm{~ns}$ & 2,62 \\
Galat & 24 & 209,452087 & 8,727170 & & \\
\hline Total & 29 & 235,826721 & & &
\end{tabular}

KK $=67,65 \%$

Keterangan $: \mathrm{ns}=$ non significant

Tabel 20. Pengaruh NAA Terhadap Berat Tunas

(Table 20. Effect of NAA on Shoot Weight)

\begin{tabular}{cc}
\hline Perlakuan & Rata-rata Berat Tunas \\
\hline $\mathrm{NAA}_{0}$ & $0,36 \mathrm{~b}$ \\
$\mathrm{NAA}_{1}$ & $0,36 \mathrm{~b}$ \\
$\mathrm{NAA}_{2}$ & $0,19 \mathrm{a}$ \\
$\mathrm{NAA}_{3}$ & $0,17 \mathrm{a}$ \\
$\mathrm{NAA}_{4}$ & $0,14 \mathrm{a}$ \\
$\mathrm{NAA}$ & $0,16 \mathrm{a}$ \\
\hline BNT 5\% & 0,14 \\
\hline
\end{tabular}

Keterangan: Angka yang diikuti dengan huruf yang sama, tidak berbeda nyata berdasarkan uji BNT 5\% 


\section{KESIMPULAN DAN SARAN}

\section{Kesimpulan}

BAP berpengaruh nyata terhadap tinggi tunas, jumlah daun, jumlah akar dan berat tunas; BAP tidak berpengaruh nyata terhadap jumlah tunas, panjang akar; Konsenterasi terbaik pada 1 ppm BAP.

Kinetin berpengaruh nyata terhadap, jumlah tunas; Kinetin tidak berpengaruh nyata terhadap jumlah daun, panjang akar, jumlah akar, berat tunas; Konsentrasi terbaik pada 3 ppm kinetin.

NAA menghambat pertambahan jumlah tunas dan berat tunas; NAA berperan sama dalam konsenterasi yang berbeda seperti terhadap tinggi tunas, jumlah daun, jumlah akar dan panjang akar.

\section{Saran}

Dalam perbanyakan krisan kulo sebaiknya menggunakan 3 ppm kinetin, sedangkan untuk perakaran dapat digunakan 1 ppm NAA.

\section{DAFTAR PUSTAKA}

Armini, N. M., G. A. Wattimena dan L.W. Gunawan. 1992. Perbanyakan Tanaman. p.12-101. in G.A Wattimena. Bioteknologi Tanaman I. Departemen $\mathrm{P}$ dan $\mathrm{K}$ Dirjen Pendidikan Tinggi PAU Bioteknologi IPB Bogor.

Ashari, S. 1995. Hortikultura. Aspek Budidaya. U.I Press Jakarta.

Arinto, N. dan H. Sugito. 1996. Pedoman Pelaksanaan Tehnik Kultur Jaringan. Penebar Swadaya Jakarta.

Bhojwani, S. and M. K. Razdan. 1983. Plant Tissue Culture. Theori and Practice. Elsevier Amsterdam.
Gambor, O. L. and D.E. Shyluk. 198I. Nutrition, Media and Characteristics of Cell and Tissue Culture. in TA Thorpe (ed) Plant Tissue Culture, Methods and Aplication in Agriculture Academic Press Inc, New York.

Diennazola, R. 2012. Tambang Emas Warna Warni. Agrina Inspirasi Agribisnis Indonesia..

George, E. F. and P.D Sherington. 1984. Plant Propagation by Tissue culture. Hand book and Directory of Commercial Laboratories. Exegetic LTD England.

Gunawan, L. B. 1987. Tehnik Kultur Jaringan. Laboratorium Kultur Jaringan Tanaman. PAU Bioteknologi IPB Bogor.

Hartman, H. T. and D.E. Kester. 1983. Plant Propagation. Principle and Practices 4 th ed. Prentice Hall inc. England New Yersey.

Sarwono, B. 1992. Mempertahankan Kesegaran Bunga Potong. Trubus 23 Hal. 15-23 .

Tim Direktorat Bina Produksi Hortikultura. 1988. Tanaman Hias; Bunga Potong; Tanaman Pot. Jakarta.

Sompotan, S. dan W. Tilaar. 2009. Induksi Tunas dari Beberapa Eksplan Krisan dalam Media MS yang dilengkapi dengan Benzilamino purin. Laporan penelitian IPTEK dan Seni Unsrat.

Zaer, J. B. and M.O. Mapes. 1982. Action of Growth Regulators. In: Tissue Culture in Forestry. Martinus Nijhoff. Publishers, Dordrecht. The Nederland. 